\title{
HRGC Study of Sorption and Desorption of Atrazine, Ametryn and Metolachlor on Brazilian Soils
}

\author{
Maria Eugênia C. Queiroz and Fernando M. Lanças* \\ Universidade de São Paulo, Instituto de Química de São Carlos, C.P. 780, \\ 13560-970 São Carlos -SP, Brasil; e-mail: flancas@iqsc.sc.usp.br
}

Received: September 27, 1995; September 27, 1996

\begin{abstract}
Os processos de adsorção e dessorção dos herbicidas ametrina, atrazina e metolaclor foram estudados em cinco solos brasileiros com diferentes conteúdos de matéria orgânica, utilizando-se cromatografia gasosa de alta resolução (HRGC). As linhas de regressão geradas apresentaram coeficiente de determinação $>0,964$, indicando um bom ajuste dos dados à equação de Freundlich. O equilíbrio de adsorção foi atingido em aproximadamente 6 h. Histerese foi observada nas isotermas de adsorção e dessorção. Correlações significativas foram encontradas entre o coeficiente de adsorção, matéria orgânica e capacidade de troca de cátions. Não foram observadas correlações entre o coeficiente de adsorção dos herbicidas (ametrina, atrazina e metolaclor) e solubilidade em água, pKa e massa molecular destes compostos, pois estes herbicidas não pertencem à mesma família química. Por este fato, as correlações entre adsorção e propriedades dos herbicidas citadas acima foram estabelecidas somente entre as triazinas. O coeficiente de adsorção das triazinas mostrou-se diretamente correlacionado com a solubilidade em água, pKa e massa molecular destes compostos nos solos avaliados.
\end{abstract}

The sorption and desorption of herbicides ametryn, atrazine and metolachlor were studied in five Brazilian soils with various organic matter contents using high resolution gas chromatography (HRGC). The regression lines generated presented a coefficient of determination $>0.964$, which indicates a good fit of the data by the Freundlich equation. Sorption reached an apparent equilibrium in the soils within approximately $6 \mathrm{~h}$. Hysteresis was observed in both sorption and desorption isotherms. Significant correlations were found among sorption of herbicides, organic matter, and cation-exchange capacity. No relationship was found between adsorption of the herbicides (ametryn, atrazine, and metolachlor) and their water solubility, pKa, and molecular mass, since these herbicides do not belong to the same chemical family. On account of this, the relationship between sorption and herbicide properties cited above was established only for s-triazines. The s-triazine adsorption showed a direct relationship with water solubility, pKa and molecular mass of these compounds on the studied soils.

Keywords: adsorption, desorption, herbicides, soils

\section{Introduction}

Metolachlor, atrazine and ametryn are widely used as selective pre-and post-emergence herbicides for weed control in sugar cane, citrus fruit, soybeans and other economically important crops in Brazil. Residues of these herbicides are frequently found in environmen- tal samples of soil and water due to their persistence and relatively high water solubility 1,2 .

Information on the adsorption and desorption potential of herbicides is needed under certain circumstances to assess movement and persistence in a soil environment. Better understanding of these processes will allow more effective weed control with minimum residues. 
Sorption is a general term that ain cludes adsorption (surface binding) and partitioning. Desorption is the re verse process of sorption. As soil-applied herbicides are generally considered to enter plant roots as solutes with the soil water, the degree of adsorption modifies the availability of herbicide to plants or the activity of the herbicide.

Organic herbicides adsorb on both organic and inorganic surfaces depending upon the chemical properties of the adsorbents and adsorbates involved.

Physical and chemical properties of the herbicides influencing adsorption and desorption processes are the chemical character, shape, configuration, acidity or basicity of molecule ( $\mathrm{pKa}$ or $\mathrm{pKb}$ ), water solubility, charge distribution on the organic cation, polarity, molecular size and polarizability ${ }^{4}$.

Some extensive adsorption studies involving a serie of analogous s-triazines have been realized. S-triazines are adsorbed by various soil constituents in strik ingly different degrees. Clay minerals, organic matter and $\mathrm{pH}$ are the soil properties mainly responsible for the ad sorption process in soil ${ }^{5-8}$. The adsorption of the acetani lide herbicides has been shown to increase with increases in the organic matter content of the soils, herbicide concentration, and temperature ${ }^{9,10}$.

This means that the adsorption process is dependent on the type of soil under consideration and the climatic conditions of a given location. The results obtained by researchers in this area are difficult to extrapolate to conditions distinct from those where the data were ob tained. In addition, data concerning the adsorption processes of pesticides on Brazilian soils is very scarce 11,12 . The indicators of the environmental quality presently in use were established with the view to attend to ecological characteristics existing in other countries, not necessarily those predominant in Brazil.

The adsorption processes on soils has usually been determined by radio-tracer techniques (conventional method), using ${ }^{14} \mathrm{C}$ - labeled material diluted with pesti cides and quantitative analysis by liquid scintillation spectrometry $^{13-15}$.
Lanças et al. ${ }^{16}$ reported the viability of the use of capillary gas chromatography as an analytical method to determined the adsorption of trifluralin in soils.

Thus, the purpose of this paper was to evaluate the sorption and desorption of herbicides, two s-triazines (atrazine and ametryn) and one acetanilide (metolachlor), on five Brazilian soils, under laboratory conditions using high resolution gas chromatography (HRGC). The relationship among sorption, the physicochemical properties of these herbicides and soil components was established.

\section{Materials and Methods}

\section{Soils}

Five types of soils with no recent history of herbicide application and representing a good range in organic matter content were used in the sorption studies. Each soil sample was obtained by the mixture of twenty different collection points from 0 to $20 \mathrm{~cm}$ depths. Before use, the soils were air-dried and ground to pass a $2.0 \mathrm{~mm}$ sieve. Table 1 shows the characteristics of these soils.

\section{Herbicides}

Technical-grade samples of ametryn [2-ethylamino-4-(isopropylamino)-6-(methylthio)- 1, 3, 5 -triazine], atrazine [2-chloro-4-(ethylamino)-6-(isopropylamino)-1, 3, 5-triazine], and metolachlor [2-chloro- 6'ethyl - N -(2-methoxy - 1 - methylethyl) acet - o toluidide] were obtained in the local trade. The properties of these herbicides are illustrated in Table 2.

\section{Adsorption equilibrium}

To establish when herbicide adsorption reached equilibrium in the soil systems, $10 \mathrm{~mL}$ of the herbicide solution, $20 \mu \mathrm{g} / \mathrm{mL}$ (in 0.01 Maqueous $\mathrm{CaCl}_{2}$ ) was added to $2 \mathrm{~g}$ of soils no. 1 and 5 in glass tubes. Duplicate samples plus blanks (no soil) used as control standards were shaken for $0.25,1,3,6,12,24 \mathrm{~h}$. The tubes were centrifuged for 15 min at $4000 \mathrm{rpm}$. The supernatant was filtered. Suitable aliquots were taken for gas chromatographic analysis.

Table 1. The chemical and physical properties of the soils evaluated.

\begin{tabular}{llcccccc}
\hline Soil & Region & $\mathrm{OM}^{(\mathrm{a})} \%$ & $\mathrm{pH}^{(\mathrm{b})}$ & $\begin{array}{c}\text { C.E.C. } \\
\text { meq/100 } \mathrm{g}\end{array}$ & Clay $^{(\mathrm{d})} \%^{*}$ & Silt $^{(\mathrm{d})} \%$ & Culture \\
\hline 1 & Ponguai SP & 0.8 & 4.3 & 2.8 & 8.4 & 7.04 & citrus \\
2 & Batatais SP & 1.6 & 5.3 & 5.3 & 21.5 & 6.36 & cane \\
3 & Aguai SP & 2.1 & 4.2 & 4.4 & 9.6 & 10.39 & - \\
4 & GuardaMor MG & 2.7 & 4.3 & 6.3 & 56.9 & 32.11 & coffe \\
5 & Sales de Oliveira SP & 5.1 & 5.9 & 16.7 & 27.0 & 55.76 & cane \\
\hline
\end{tabular}

(a) OM = Organic Matter (Ref. 17); (b) from Ref.17; (c) CEC = Cation-Exchange-Capacity (Ref. 18); (d) Particle size distribution classes: silt = 0.05 to $0.002 \mathrm{~mm}$, clay $=<0.002 \mathrm{~mm}$ (Ref. 18). 
Table 2. Properties of the herbicides studied.

\begin{tabular}{lccc}
\hline Herbicides & $\begin{array}{c}\text { Solubility } \\
\text { Water }\end{array}$ & $\mathrm{ppm}^{(\mathrm{a})}$ & $\mathrm{pKa}^{(\mathrm{a})}$ \\
\hline Ametryn & 193 & 3.12 & 227.3 \\
Atrazine & 33 & 1.68 & 215.7 \\
Metolachlor & 500 & (b) & 283.8 \\
\hline
\end{tabular}

(a) from Ref. 19; (b) $100 \%$ of metolachlor in solution is in the molecular form (Ref. 9).

\section{Adsorption}

Stock solutions of herbicides were made in $0.01 \mathrm{M}$ $\mathrm{CaCl}_{2}$ at concentrations below that corresponding to their maximum solubility in water (Table 2 ). The stock solutions were diluted with $0.01 \mathrm{M} \mathrm{CaCl}_{2}$ to yield five concentrations $(1,5,10,20,30 \mu \mathrm{g} / \mathrm{mL})$ that were used in subsequent experiments. Two grams of soil were shaken with $10 \mathrm{~mL}$ of each herbicide solution in a glass tube for $6 \mathrm{~h}$ at room temperature $\left(25 \pm 2{ }^{\circ} \mathrm{C}\right)$. All treatments were performed in duplicate, and appropriate blanks (no soil) at each desired concentration were run. The tubes were centrifuged at 4000 rpm for $15 \mathrm{~min}$ and aliquots of the supernatant were filtered and taken for analysis. The amount adsorbed (micrograms of herbicide per gram of soil) was determined by the difference between the blank and treatment values; i.e.

$$
\mathrm{A}=\frac{\mathrm{v}}{\mathrm{W}}\left(\mathrm{C}_{B}-\mathrm{Ce}\right)
$$

where $\mathrm{A}$ is the amount adsorbed, $\mathrm{v}$ the solution volume $(\mathrm{mL}), \mathrm{w}$ is the mass of soil in grams, $\mathrm{C}_{\mathrm{B}}$ is the equilibrium concentration of blank $(\mu \mathrm{g} / \mathrm{mL})$, and $\mathrm{Ce}$ is the equilibrium concentration in the supernatant $(\mu \mathrm{g} / \mathrm{mL})$.

\section{Desorption}

Soil samples were shaken with solutions of atrazine, ametryn and metolachlor as described for adsorption. After centrifugation and removal of aliquots for gas chromatographic analysis, the remaining supernatant was carefully decanted. Ten milliliters of $0.01 \mathrm{M} \mathrm{CaCl}_{2}$ were added to the tubes, and the samples were shaken for $6 \mathrm{~h}$. The tubes were centrifuged, and aliquots of supernatant were filtered and removed for analysis. Desorption, expressed as micrograms adsorbed per gram of soil, was determined by difference, taking to in account the solution remaining in the soil after the supernatant was poured off.

\section{Herbicide analysis}

The herbicide concentrations in the supernatant were determined by high resolution gas chromatography (HRGC) using the following conditions:
Ametryn: SRI - 8610 chromatograph equipped with flame ionization detector (FID); fused silica column, LM 1 (100\% cross-linked dimethyl polysiloxane) $-25 \mathrm{~m} \mathrm{x}$ $0.53 \mathrm{~mm} \times 1 \mu \mathrm{m}$; temperatures: column $=190{ }^{\circ} \mathrm{C}-6{ }^{\circ} \mathrm{C} / \mathrm{min}$ $-240^{\circ} \mathrm{C}$; injector $=$ cold "on column" injector, operated at the ambient temperature $\left(25^{\circ} \mathrm{C}\right)$, detector $=300^{\circ} \mathrm{C}$; carrier gas, $\mathrm{H}_{2}$ at a linear velocity of $53.50 \mathrm{~cm} / \mathrm{s}$.

Atrazine: HP 5890 - Serie II chromatograph equipped with flame ionization detector (FID); fused silica column, LM 5 (5\% dimethyl phenyl polysiloxane) - $15 \mathrm{~m}$ x $0.32 \mathrm{~mm}$ x $0.25 \mu \mathrm{m}$; temperatures, column $=160{ }^{\circ} \mathrm{C}(10 \mathrm{~min})$ $8{ }^{\circ} \mathrm{C} / \mathrm{min}-300{ }^{\circ} \mathrm{C}$, injector $=250{ }^{\circ} \mathrm{C}$, detector $=300{ }^{\circ} \mathrm{C}$; carrier gas $\mathrm{H}_{2}$ at a linear velocity of $40 \mathrm{~cm} / \mathrm{s}$ and split ratio of $1: 30$.

Metolachlor: SRI - 8610 chromatograph equipped with flame ionization detector (FID); fused silica column, LM 1 (100\% cross-linked dimethyl polyxiloxane) - $25 \mathrm{~m}$ x 0.53 mm x $1 \mu \mathrm{m}$; temperatures: column, $180{ }^{\circ} \mathrm{C}-6{ }^{\circ} \mathrm{C} / \mathrm{min}-220$ ${ }^{\circ} \mathrm{C}$; injector $=$ cold "on column" injector, operated at the ambient temperature $\left(25^{\circ} \mathrm{C}\right)$, detector $=300^{\circ} \mathrm{C}$; carrier gas, $\mathrm{H}_{2}$ at a linear velocity of $53.50 \mathrm{~cm} / \mathrm{s}$.

\section{Results and Discussion}

\section{Gas chromatographic analysis}

In literature there are few articles using chromatography methods in adsorption studies and the majority of these, use reverse-phase HPLC ${ }^{10,20,26,28}$. The chromatography methods are more sensitivity (lower detection limits) when compared with radio-tracer techniques (conventional method) and other disadvantages of the conventional methods are the necessity of the use of ${ }^{14} \mathrm{C}$ labelled pesticides with high radiochemical purity, especially in Brazil, where these compounds are expensive, slow to obtain due to dependence on importation, and are necessary adequate discard.

No degradation of the herbicides was observed in the absence of adsorbent material (soil), since a constant concentration of herbicide was observed throughout the experiment, and no new peak appeared on the chromatograms. The chromatograms referring to the adsorption phenomenon for each individual herbicide are shown in Fig. 1.

\section{Adsorption isotherms}

On the basis of the kinetic experiments, the adsorption of herbicides by the soils reached an apparent equilibrium after $6 \mathrm{~h}$.

The empirical Freundlich relationship was used to describe the results of adsorption. The linear form of this equation is as follows:

$$
\log \frac{\mathrm{x}}{\mathrm{m}}=\log \mathrm{K}+\frac{1}{\mathrm{n}} \log \mathrm{Ce}
$$




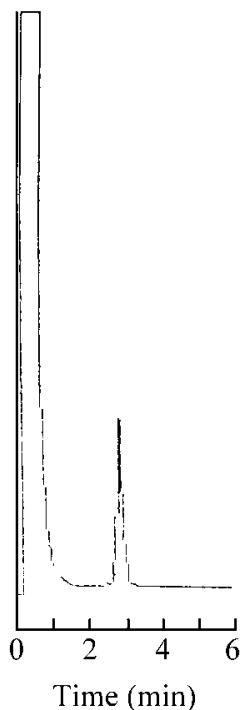

(a)

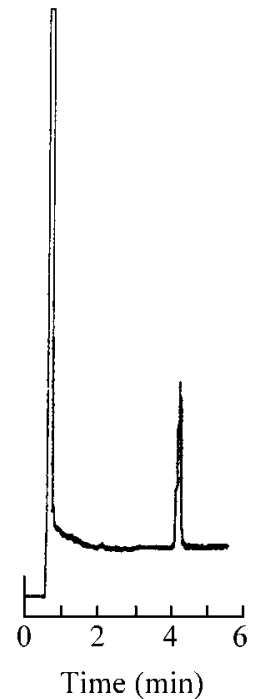

(b)

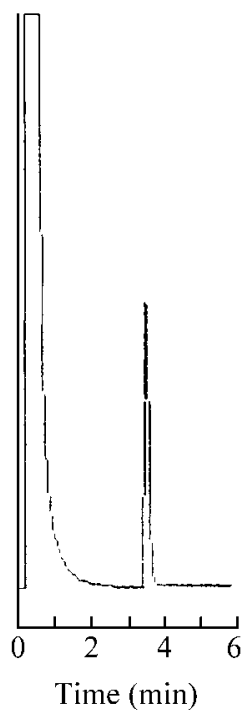

(c)
Figure 1. Chromatograms referring to the adsorption of herbicides: (a) ametryn, (b) atrazine, and (c) metolachlor.

where $\mathrm{x} / \mathrm{m}$ is the concentration of the adsorbate per unit amount of adsorbent $(\mu \mathrm{g} / \mathrm{g}), \mathrm{Ce}$ is the adsorbate concentration in solution after equilibration $(\mu \mathrm{g} / \mathrm{mL})$, and $\mathrm{K}$ and $1 / \mathrm{n}$ are constants relative to the affinity of adsorbent for adsorbate and to the degree of curvature of the isotherm, respectively. The $\mathrm{K}$ value can be used to compare sorption of different herbicides on various soils at unit concentration ${ }^{15}$.
Log-log plots of herbicide (ametryn, atrazine, and metolachlor) adsorption on each soil type yielded straight, parallel lines (Fig. 2). The general shapes of the adsorption isotherms were very similar, suggesting that similar adsorption mechanisms were involved.

Freundlich constants $\mathrm{K}$ and $1 / \mathrm{n}$ and the corresponding coefficient of determination $\left(\mathrm{r}^{2}\right)$ are given in Table 3. Most of the regression lines generated had a coefficient of determination $\left(\mathrm{r}^{2}\right)>0.964$ which indicated a good fit of the data by the Freundlich equation ${ }^{20}$.

No limiting adsorption was observed within the concentrations range used. As the concentration of herbicides was increased, the amount adsorbed increased in almost linear fashion with these concentrations.

Desorption isotherms represent the micrograms of herbicide still adsorbed per gram of soil as a function of equilibrium concentration after one desorption cycle. Adsorption was partially reversible, the desorption values were smaller than those for adsorption (Table 3). Noncoincidence of adsorption and desorption isotherms is called hysteresis ${ }^{21}$ and it indicates that a different range or spectrum of forces are involved in adsorption than in desorption. Hysteresis has been observed in other herbicide adsorption studies ${ }^{22-24}$. The reversibility of adsorption plays an important role in herbicide control in agriculture.

\section{Soil properties affecting the adsorption phenomena}

The relationship between sorption and soil properties was determined through simple correlation analysis (Table 4). Strong correlations were found among organic matter

Table 3. Freundlich constants and coefficient of determination $\left(\mathrm{r}^{2}\right)$ for herbicide adsorption and desorption.

\begin{tabular}{|c|c|c|c|c|c|c|c|c|c|c|c|c|}
\hline \multirow[b]{3}{*}{ Soils } & \multicolumn{11}{|c|}{ Adsorption } & \\
\hline & \multicolumn{4}{|c|}{ Ametryn } & \multicolumn{4}{|c|}{ Atrazine } & \multicolumn{4}{|c|}{ Metolachlor } \\
\hline & $\mathrm{K}$ & $1 / \mathrm{n}$ & $r^{2}$ & (a) Kom & $\mathrm{K}$ & $1 / \mathrm{n}$ & $r^{2}$ & Kom & $\mathrm{K}$ & $1 / \mathrm{n}$ & $r^{2}$ & Kom \\
\hline 1 & 1.54 & 0.84 & 0.974 & 192.50 & 0.81 & 0.88 & 0.938 & 101.25 & 0.53 & 1.05 & 0.998 & 66.25 \\
\hline 2 & 5.23 & 0.91 & 0.972 & 326.87 & 1.98 & 0.94 & 0.999 & 123.75 & 0.79 & 1.03 & 0.999 & 49.37 \\
\hline 3 & 4.48 & 0.89 & 0.965 & 213.33 & 1.23 & 1.28 & 0.995 & 58.57 & 0.71 & 0.96 & 0.998 & 35.23 \\
\hline 4 & 7.45 & 0.99 & 0.998 & 288.88 & 3.58 & 0.93 & 0.972 & 170.74 & 1.06 & 1.02 & 0.999 & 39.25 \\
\hline \multirow[t]{2}{*}{5} & 10.39 & 0.89 & 0.840 & 223.13 & 5.75 & 0.96 & 0.963 & 112.74 & 4.10 & 1.03 & 0.999 & 78.62 \\
\hline & \multicolumn{4}{|c|}{$\Delta \mathrm{G}=-3.26^{(\mathrm{b})}$} & \multicolumn{4}{|c|}{$\Delta \mathrm{G}=-2.79$} & \multicolumn{3}{|c|}{$\Delta \mathrm{G}=-2.35$} & \\
\hline \multicolumn{13}{|c|}{ Desorption } \\
\hline 1 & 0.46 & 0.87 & 0.993 & 61.25 & 0.42 & 0.88 & 0.978 & 52.5 & 0.14 & 1.05 & 0.997 & 17.50 \\
\hline 2 & 0.65 & 1.16 & 0.983 & 50.62 & 0.80 & 0.95 & 0.996 & 50.0 & 0.46 & 1.02 & 0.997 & 28.75 \\
\hline 3 & 0.81 & 0.95 & 0.892 & 30.95 & 1.46 & 0.84 & 0.953 & 69.52 & 0.26 & 0.98 & 0.999 & 12.38 \\
\hline 4 & 2.13 & 1.06 & 0.942 & 78.88 & 1.64 & 0.94 & 0.986 & 60.74 & 0.57 & 1.03 & 0.998 & 21.11 \\
\hline \multirow[t]{2}{*}{5} & 3.19 & 1.10 & 0.895 & 62.54 & 1.60 & 1.05 & 0.994 & 31.37 & 1.85 & 0.98 & 0.995 & 36.07 \\
\hline & \multicolumn{4}{|c|}{$\Delta \mathrm{G}=-2.39$} & \multicolumn{4}{|c|}{$\Delta \mathrm{G}=-2.34$} & \multicolumn{4}{|c|}{$\Delta \mathrm{G}=-1.85$} \\
\hline
\end{tabular}

(a) Kom = K . $100 / \mathrm{OM} \%$; (b) $\Delta \mathrm{G}$-Free Energy Change, kcal / mol. 

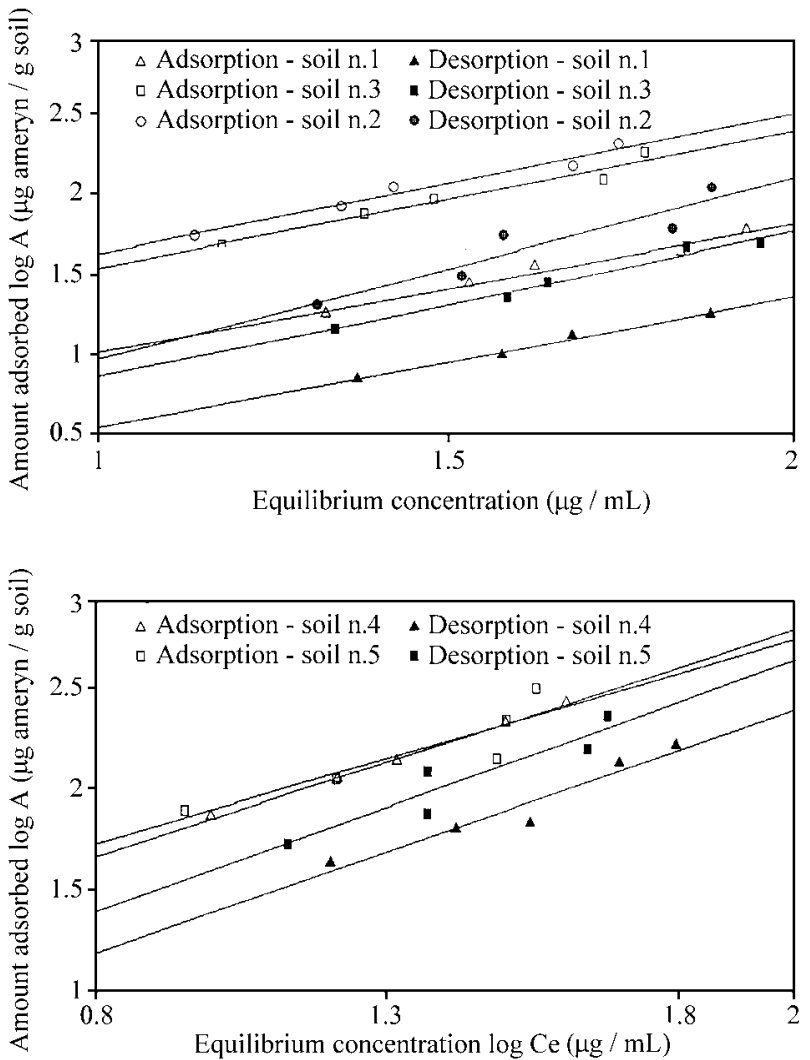

Figure 2. Freundlich isotherms for ametryn adsorption and desorption on five soils.

content (O.M.), cation-exchange capacity (C.E.C.), and degree of adsorption $(\mathrm{K})$ of the herbicides evaluated. The soils with high values of O.M. and C.E.C. require higher rates of herbicide application to maintain a given level of herbicidal activity than do soils with lower values of these properties.

The importance of organic matter in adsorption processes was also reported by several authors. Sequi et $a .^{25}$ related that the sorption ability for atrazine and triluralin were increased consideralably in soils with high organic matter content. The adsorption of ametryn was positively correlated with organic matter and silt content ${ }^{26}$. These data agree with correlation observed for this triazine (Table $4)$.

Table 4. Simple correlation coefficients (r) between K values and soil properties determined.

\begin{tabular}{lccl}
\hline Herbicides & OM \% & CEC & CLAY \\
\hline Ametryn & $0.939 * *$ & $0.896 * *$ & $0.594 * * * * *$ \\
Atrazine & $0.898^{* *}$ & $0.853 * * *$ & $0.730 * * * *$ \\
Metolachlor & $0.947 * *$ & $0.993 *$ & $0.205 * * * * *$ \\
\hline
\end{tabular}

Significance at $0.1 \%$ level (*), $1 \%$ level (**), $2 \%$ level (***), $<10 \%$ level $(* * * *)$, and $10 \%$ level $(* * * * *)$.
Weber and Peter ${ }^{27}$ demonstrated that organic matter was the primary adsorbing surface in soils for acetanilide herbicides. Obrigawitch et al. ${ }^{22}$ calculated the coefficient of determination $\left(\mathrm{r}^{2}\right)$ values for percent organic carbon and clay versus the metolachlor Freundlich adsorption constant (K) for three soils. Organic carbon versus K resulted in $\mathrm{r}^{2}=$ 0.92 , and clay versus K resulted in $r^{2}=0.68$. The coefficient of determination $\left(\mathrm{r}^{2}\right)$ value between organic matter content and metolachlor $\mathrm{K}$ is very similar to the correlation coefficient $r=0,947$ calculed in this work for the same compound.

Significant correlation was also observed among organic matter and clay content of other Brazilian soils (from the "cerrado" of the State of São Paulo) and sorption coefficient of aldrin, malathion, and parathion ${ }^{28}$.

The regression equations between degree of adsorption (K) of the herbicides and the considered properties of soils were:

Ametryn

$\mathrm{K}=-0.5891+2.6273$ O.M. -0.1361 C.E.C.

Atrazine

$\mathrm{K}=-0.15758+1.4740$ O.M. - 0.0834 C.E.C.

Metolachlor

$\mathrm{K}=-0.3662-0.1619$ O.M. +0.3085 C.E.C.

If the $\mathrm{K}$ value in the Freundlich equation is replaced by the one found from equations 3 to 5 , a simple relationship may be established between herbicide (ametryn, atrazine and metolachlor) adsorption and soil properties. This may be useful for calculation of the quantity of herbicides to be applied in order to achieve greater efficiency ${ }^{29}$.

Sorption relationships between herbicides were illustrated in a different manner by normalizing the Freundlich $\mathrm{K}$ constants to a $1 \mathrm{~g}$ organic matter basis. The new constant, Kom, was averaged for each herbicide over the five soil types (Table 3). The order of increasing Kom was similar to that for the simple $\mathrm{K}$ constants.

Assuming that the herbicides were adsorbed mainly by organic matter, the change in free energy for adsorption was calculated for herbicides by using the mean value for $\mathrm{K}^{`} \mathrm{om}^{10}$.

$$
\Delta \mathrm{G}=-\mathrm{R} \mathrm{T} \ln \mathrm{K}^{\prime} \mathrm{om}
$$

where $\Delta \mathrm{G}$ is the free energy change ( $\mathrm{kcal} / \mathrm{mol}), \mathrm{R}$ is the gas constant $(1.986 \mathrm{cal} / \mathrm{Kmol})$, and $\mathrm{T}$ is absolute temperature. All $\Delta \mathrm{G}$ for herbicide adsorption were negative, as expected for a spontaneous reaction (Table 3). In general the numerically smaller values of $\Delta \mathrm{G}$ corresponded to the samples with the lower adsorption capacity.

Herbicide properties affecting adsorption 
Freundlich isotherms (Fig. 4) showed differences in adsorption between herbicides in distinct soils. Sorption of lindane varied in different Brazilian soils ${ }^{12}$. Felsot and $\mathrm{Dahm}^{15}$ related that the variable Freundlich isotherms for different pesticides-soil system indicate that sorption is a complex phenomenon involving different types of adsorption sites with different surface energies

Ametryn (methlymercapto-triazine) was adsorbed by all the soils more than all others herbicides investigated (Table 3).

Weber and Peter ${ }^{27}$ found two to three fold higher adsorption of prometryn (methylmercapto-triazine) than for the acetanilide herbicides: alachlor, acetolachlor, and metolachlor.

No relationship was found between sorption of herbicides (ametryn, atrazine, and metolachor) and their water solubility, pKa, and molecular mass, Table 2. This is what would be expected since these herbicides do not belong to the same chemical family. On account of this, the relationship between sorption and herbicide properties cited above will be established only for s-triazines.

The s-triazine adsorption ability showed a direct relationship with water solubility, $\mathrm{pKa}$ and molecular mass of these componds in the soils evaluated. This result supports the premise that the adsorption increases with the molecular mass of adsorbate in the same chemical family ${ }^{10}$.

This study suggests that atrazine (chloro-derivatives) would be adsorbed in lower amounts by the studied soils than ametryn (methylmercapto-derivatives). Analogous results were obtained in previous studies when s-triazines were adsorbed on soil organic matter ${ }^{7}$.Ametryn, showing a pKa value of 3.12, presents a more basic character than atrazine, pKa 1.68. The increasing basicity can be explained in terms of the presence of more nucleophilic groups on the molecule. The basicity appears to be important in the overall adsorption-desorption reaction, especially if the adsorbed material presents a basic character. Proton transfer from protonated species adsorbed on a soil surface to an uncharged molecule at the soil surface has been shown to be dependent upon the relative basicities of two interacting compounds as well as the relative concentrations or activities of reactants and products ${ }^{4}$.

In conclusion, the affinity between molecules of the s-triazines studied and soil particles showed to be dependent upon the chemical properties of the soils (organic matter, and cation-exchange capacity) and the chemical properties (water solubility, pKa, molecular mass) of the s-triazines involved.

\section{References}

1. Huang, L.Q. J. Assoc. off. Anal. Chem. 1989, 72, 349.

2. Sánchez, C.; Brunete, L.; Martinez, L.; Tadeo, J.L. J. Agric. Food. Chem. 1994, 42, 2210.
3. Yeager, R.L.; Halley, B.A. J. Agric. Food. Chem. 1990, $38,883$.

4. Bailey, G.W.; White, J.L. Resid. Rev. 1970, 32, 30.

5. Bailey, G.W.; White, J.L.; Rothberg, T. Soil Sci. of Amer. Proceed. 1968, 32, 222.

6. Sullivan, J.D.; Felbeck, G.T. Soil Sci. 1968, 42, 106.

7. Weber, J.B.; Weed, S.B.; Ward, T.M. Weed Sci. 1969, 17, 417.

8. Weber, J.B. Resid. Rev. 1970, 32, 93.

9. Kozak, J.; Weber, J.B.; Sheets, T.J. Soil Sci. 1983, 136, 94.

10. Sato, T.; Kohnosu, S.; Hartwig, J.F. J. Agric. Food. Chem. 1987, 35, 397.

11. Lord, K.A.; Helene, C.G.; Ruegg, E.F. Arq. Inst. Biol. 1978, 45, 47.

12. Luchini, L.C.; Lord, K.A.; Ruegg, E.F. Ciênc. Cult. 1981, 33, 97.

13. Wahid, P.A.; Sethunathan, N. J. Agric. Food. Chem. 1978, 26, 101.

14. Yeager, R.L.; Halley, B.A. J. Agric. Food Chem. 1990, $38,883$.

15. Felsot, A.; Dahm, P.A. J. Agric. Food. Chem. 1979, 3, 557.

16. Lanças, F.M.; Vilegas, J.H.Y.; Galiane, M. S. Pesticidas 1994, 4, 39.

17. Raij, B.V.; Quagio, J.A.; Cantarella, H. In Análise Química do Solo Para Fins de Fertilidade; Fundação Cargil, Campinas, 1987.

18. Camargo, O.A.; Moniz, A.C.; Jorge, J.A. In Métodos de Análise Química, Mineralógica e Física de Solos do Instituto Agronômico de Campinas; Instituto Agronômico, Campinas, 1986.

19. Best, C.E. In Herbicide Handbook; Ed.; Weed Science of America; Champaign, IIIinois, 1993.

20. Gennari, M.; Negre, M.; Raimondo, E. J. Agric. Food. Chem. 1994, 42, 2329.

21. Bowman, B.T.; Sans, W. J. Environ. Qual. 1985, 14, 270.

22. Obrigawitch, T.; Hons, F.M.; Abernathy, J.R.; Gipson, J.R. Weed Sci. 1981, 3, 332.

23. Swanson, R.A.; Dutt, G.R. Soil Sci. Soc. Amer. Proc. 1973, 37, 872 .

24. Gilchrist, G.F.R.; Gamble, D.S.; Khan, S. U. J. Agric. Food Chem. 1993, 41, 1748.

25. Sequi, P.; Francioso, O.; Bak, E. Sci. of the Total Environ. 1992, 123, 503.

26. Lui, L.C.; Cibes-Viadé, H.; Koo, F.K.S. Weed Sci. 1970 , 18,470 .

27. Weber, J.B.; Peter, C.J. Weed Sci. Soc. Am. Abstr. 1980, $221,102$.

28. Luchini, L.C.; Hirata, R.; Ruegg, E.F. Pesq. Agropec. Bras. 1984, 19, 157.

29. Dios Canela, G.; Romero Taboada, E.; Sánchez Rasero, F. J. of Soil Sci. 1992, 43, 99.

FAPESP helped in meeting the publication costs of this article 